Maria R. Bonsignore, Giuseppe Morici, Roberta Riccioni, Alice Huertas, Eleonora

Petrucci, Mario Veca, Gualtiero Mariani, Anna Bonanno, Laura Chimenti, Maria

Gioia, Paolo Palange and Ugo Testa

J Appl Physiol 109:60-67, 2010. First published May 6, 2010; doi:10.1152/japplphysiol.01344.2009

You might find this additional information useful...

This article cites 42 articles, 23 of which you can access free at:

http://jap.physiology.org/cgi/content/full/109/1/60\#BIBL

Updated information and services including high-resolution figures, can be found at:

http://jap.physiology.org/cgi/content/full/109/1/60

Additional material and information about Journal of Applied Physiology can be found at: http://www.the-aps.org/publications/jappl

This information is current as of October 10, 2010 .

Journal of Applied Physiology publishes original papers that deal with diverse areas of research in applied physiology, especially those papers emphasizing adaptive and integrative mechanisms. It is published 12 times a year (monthly) by the American

Physiological Society, 9650 Rockville Pike, Bethesda MD 20814-3991. Copyright (C) 2010 by the American Physiological Society.

ISSN: 8750-7587, ESSN: 1522-1601. Visit our website at http://www.the-aps.org/. 


\title{
Hemopoietic and angiogenetic progenitors in healthy athletes: different responses to endurance and maximal exercise
}

\author{
Maria R. Bonsignore, ${ }^{1,5}$ Giuseppe Morici, ${ }^{2,5}$ Roberta Riccioni, ${ }^{3}$ Alice Huertas, ${ }^{4}$ Eleonora Petrucci, ${ }^{3}$ \\ Mario Veca, ${ }^{2}$ Gualtiero Mariani, ${ }^{3}$ Anna Bonanno, ${ }^{5}$ Laura Chimenti, ${ }^{1}$ Maria Gioia, ${ }^{1}$ Paolo Palange, ${ }^{4}$ \\ and Ugo Testa ${ }^{3}$ \\ ${ }^{1}$ Biomedical Department, Internal and Specialistic Medicine (DIBIMIS), Section of Pneumology, University of Palermo, \\ Palermo; ${ }^{2}$ Department of Experimental Medicine (DIMES), University of Palermo, Palermo; ${ }^{3}$ Laboratory of Oncology \\ Hematology, ISS, Rome; ${ }^{4}$ Department of Clinical Medicine, "La Sapienza" University, Rome; ${ }^{5}$ Institute of Biomedicine \\ and Molecular Immunology, National Research Council (CNR), Palermo, Italy
}

Submitted 2 December 2009; accepted in final form 29 April 2010

Bonsignore MR, Morici G, Riccioni R, Huertas A, Petrucci E, Veca M, Mariani G, Bonanno A, Chimenti L, Gioia M, Palange $\mathbf{P}$, Testa $\mathbf{U}$. Hemopoietic and angiogenetic progenitors in healthy athletes: different responses to endurance and maximal exercise. J Appl Physiol 109: 60-67, 2010. First published May 6, 2010; doi:10.1152/japplphysiol.01344.2009.-The effects of endurance or maximal exercise on mobilization of bone marrow-derived hemopoietic and angiogenetic progenitors in healthy subjects are poorly defined. In 10 healthy amateur runners, we collected venous blood before, at the end of, and the day after a marathon race $(n=9)$, and before and at the end of a $1.5-\mathrm{km}$ field test $(n=8)$, and measured hemopoietic and angiogenetic progenitors by flow cytometry and culture assays, as well as plasma or serum concentrations of several cytokines/growth factors. After the marathon, $\mathrm{CD} 34^{+}$cells were unchanged, whereas clonogenetic assays showed decreased number of colonies for both erythropoietic (BFU-E) and granulocyte-monocyte (CFU-GM) series, returning to baseline the morning post-race. Conversely, CD $34^{+}$cells, BFU-E, and CFU-GM increased after the field test. Angiogenetic progenitors, assessed as $\mathrm{CD}_{3} 4^{+} \mathrm{KDR}^{+}$and $\mathrm{CD}_{133^{+} \text {VE-cadherin }}{ }^{+}$cells or as adherent cells in culture expressing endothelial markers, increased after both endurance and maximal exercise but showed a different pattern between protocols. Interleukin-6 increased more after the marathon than after the field test, whereas hepatocyte growth factor and stem cell factor increased similarly in both protocols. Plasma levels of angiopoietin (Ang) 1 and 2 increased after both types of exercise, whereas the Ang-1-to-Ang-2 ratio or vascular endothelial growth factor-A were little affected. These data suggest that circulating hemopoietic progenitors may be utilized in peripheral tissues during prolonged endurance exercise. Endothelial progenitor mobilization after exercise in healthy trained subjects appears modulated by the type of exercise. Exercise-induced increase in growth factors suggests a physiological trophic effect of exercise on the bone marrow.

angiopoietin; marathon; circulating progenitors; growth factors

RELEASE OF BONE MARROW-DERIVED progenitors $\left(\mathrm{CD} 34^{+}\right.$cells) occurs after acute exercise $(18,21,22,28,39,40)$ and might be involved in repair processes, i.e., at the level of skeletal muscle, as suggested by some experimental studies $(16,25)$. In recent years, endothelial progenitor cells (EPCs) have been extensively investigated because of their angiogenetic activity and potential usefulness in the clinical setting $(26,32)$. Particularly, recent studies in animals and humans unveiled the

Address for reprint requests and other correspondence: Maria R. Bonsignore, Biomedical Dept., Internal and Specialistic Medicine (DIBIMIS), Section of Pneumology, Univ. of Palermo, Via Trabucco, 180, 90146 Palermo, Italy (e-mail: marisa@ibim.cnr.it). ability of EPCs to ameliorate the function of ischemic organs possibly by both induction and mobilization of angiogenesis (incorporation into damaged vessels and paracrine action) and to support re-endothelization of injured arteries by replacing the dysfunctional endothelial cells $(9,37)$.

Several EPC markers have been identified $(31,33,41)$, and $\mathrm{CD}_{34}{ }^{+} \mathrm{KDR}^{+}$cells, CD $34^{+} \mathrm{CD} 133^{+}$cells, CD $133^{+} \mathrm{VE}-\mathrm{cad}-$ herin $^{+}$cells, or monocyte/macrophage-derived angiogenic cells (CACs) have been shown to increase after acute exercise $(18,27,28,40)$. As for the effects of chronic exercise, circulating EPCs increased after training in healthy subjects (17) and children (42), whereas no major change in progenitor release was reported in healthy young or older men in relation to training status (39).

EPCs could be involved in training-induced capillarization of skeletal muscle, but the mechanism(s) of their mobilization from bone marrow are still incompletely understood. Hypoxia may play a role, as suggested by the high plasma concentrations of vascular endothelial growth factor (VEGF) A found in animal models and patients with ischemic cardiovascular disease $(1,17,30,34)$. However, unchanged $(28,39)$ or increased $(8,21)$ plasma VEGF-A levels were found after exercise in normal subjects. In addition, little is known on the possible role of other angiogenetic factors, such as hepatocyte growth factor (HGF) (4), or angiopoietin (Ang) 1 and 2 in the mobilization of progenitors induced by exercise. Finally, exercise may cause release of VEGF-C or VEGF-D, which are believed to be involved in lymphangiogenesis $(12,29)$.

Athletes are the ideal population to assess the physiological effects of intense exercise and training. In our first study, flow cytometry in whole blood showed increased circulating $\mathrm{CD} 4^{+}$cells at rest in well trained runners compared with sedentary controls $(3)$. CD $34^{+}$cells were unchanged immediately after a marathon or half-marathon race but decreased on the day post-race (3). In advanced-age marathon runners, Adams and coworkers recently reported that hemopoietic progenitors decreased at the end of the marathon race, whereas the proportion of $\mathrm{CD}_{3} 4^{+} \mathrm{KDR}^{+}$cells out of the total $\mathrm{CD} 34^{+}$cells increased (2). Increased EPCs were reported up to $48 \mathrm{~h}$ postexercise in competitive runners after a $246-\mathrm{km}$ race (10). Finally, in young competitive rowers, we showed release of bone marrow-derived progenitors after supramaximal exercise ("all-out" rowing) (22).

The pattern of circulating cytokines/growth factors possibly involved in progenitor release differed after prolonged aerobic exercise (marathon or half-marathon) and all-out rowing (3, 
22), suggesting that exercise intensity and/or duration may modulate progenitor release; alternatively, the response to exercise may vary according to the type of training.

The present study was designed with two aims. The first aim was to further characterize the release and mobilization of bone marrow-derived progenitors, including angiogenetic ones, in amateur runners at rest, at the end of a marathon race, and the following morning. Different subpopulations of EPCs $\left[\mathrm{CD} 34^{+} \mathrm{KDR}^{+}\right.$cells, CD133 ${ }^{+}$VEcadherin ${ }^{+}$cells, and monocyte-derived circulating angiogenetic cells (CACs)] were assessed, together with a panel of angiogenetic mediators/growth factors [HGF, VEGF-A, -C, and -D, stem cell factor (SCF), interleukin (IL)-6]. The second aim was to compare the effects of a marathon race to those of a maximal test in the same runners, studied at rest and after $1.5 \mathrm{~km}$ of running, to further characterize progenitor release in response to endurance and maximal exercise.

\section{METHODS}

Ten healthy male amateur runners were studied. Nine subjects participated in the marathon protocol (age: $43.6 \pm 11.6 \mathrm{yr}$; training volume: $88 \pm 35 \mathrm{~km} / \mathrm{wk}$; race experience: $9.3 \pm 6.5 \mathrm{yr}$; range: $1-20$ yr), whereas eight subjects underwent the 1,500-m field test protocol (age: $43.4 \pm 10.9 \mathrm{yr}$; training volume: $90 \pm 38 \mathrm{~km} / \mathrm{wk}$ ). The two groups did not differ significantly for age or training volume. Seven subjects participated in both protocols. The study was approved by the local Ethical Committee, and written, informed consent was obtained from all subjects.

Marathon and field test. The Palermo International Marathon was held on November 20, 2005. Average race time of the group was $191 \pm 26 \mathrm{~min}$. The field tests were obtained on May 10, 2006 on a 400-m track. In the field test, subjects ran $1,500 \mathrm{~m}$ at their maximum speed after mild warm-up for $20 \mathrm{~min}$ at $75 \%$ of their maximal predicted heart rate $(\sim 130$ beats/min). Oxygen consumption was measured during the field tests (COSMED K4b), and averaged $45 \pm$ $6 \mathrm{ml} \cdot \mathrm{min}^{-1} \cdot \mathrm{kg}^{-1}$ in the last minute of exercise. Subjects covered the $1,500 \mathrm{~m}$ distance in $5 \mathrm{~min} 35 \mathrm{~s} \pm 35 \mathrm{~s}$ and attained a maximal heart rate of $178 \pm 6$ beats $/ \mathrm{min}$ (101 $\pm 5 \%$ of their maximal predicted heart rate) during the test.

Venous blood sample collection and processing. Venous blood was collected in EDTA for standard blood cell and reticulocyte counts, and in heparinized tubes for analysis of progenitors. Aliquots of plasma and serum were prepared and stored at $-80^{\circ} \mathrm{C}$ until analysis. Similar to our laboratory's previous study (3), blood samples were obtained in the marathon protocol 1 ) at rest in the morning 2 or 3 days before the race, 2 ) at the end of the race (on average $8 \pm 2$ min after arrival), and 3 ) at rest in the morning $18-20 \mathrm{~h}$ after end of the race. For the field-test protocol, blood samples were obtained on the same day, at rest before the 20-min warm-up and at 3-5 min after the end of the test, respectively. Venous blood was kept at $4{ }^{\circ} \mathrm{C}$ until analysis for total blood cell counts (ADVIA) and progenitors (see below).

Peripheral blood mononuclear cells isolation. Peripheral blood mononuclear cells (PBMCs) were obtained by standard Ficoll gradient centrifugation. Briefly, heparin-anticoagulated blood was diluted 1:1 with Iscove's Modified Dulbecco's Medium (IMDM, GIBCO), slowly pipetted on a cushion of Ficoll-Hypaque separation medium, and then centrifuged for $20 \mathrm{~min}$ at $400 \mathrm{~g}$ and $20^{\circ} \mathrm{C}$. At the end of the centrifugation, floating cells were recovered, washed three times with PBS, resuspended in IMDM medium, counted, and then used for various assays. Cell viability was used for various assays. Cell viability was assessed using the vital trypan blue supravital staining.

Flow cytometry characterization of circulating mononuclear cells. Cells were carefully washed with PBS, resuspended in PBS containing $2 \mathrm{mg} / \mathrm{ml}$ bovine serum albumin, and labeled for $30 \mathrm{~min}$ at $4^{\circ} \mathrm{C}$ with the antibody phycoerythrin (PE)-conjugated anti-CD34 (Becton
Dickinson-Pharmingen, Lincoln Park, NJ) or with PE-conjugated anti-CD133 monoclonal antibodies (Miltenyi Biotech, Bergisch Gladbach, Germany).

Circulating endothelial progenitors are thought to express CD34 and endothelial markers such as CD144 (VE-Cadherin) and KDR (VEGF-R2). These progenitors were evaluated by independent operators, blind to the data, by flow cytometry with CD34/KDR, CD34/ VE-Cadherin (CD144), and CD133/VE-Cadherin double labeling. These CD34/KDR and CD133/VE-Cadherin cells are cell populations enriched for EPCs, and their measure can be considered an indicator of the number of circulating EPCs. Briefly, for the latter, aliquots of $1 \times 10^{6}$ PBMC were incubated for $45 \mathrm{~min}$ on ice with antibodies against human CD34 (FITC-conjugated, BD Biosciences) or against human CD133 (FITC-conjugated, Miltenyi) and either KDR or VE-Cadherin (PE-conjugated, R\&D Systems). Respective isotypematched FITC- or PE-conjugated antibodies from the same manufacturers served as controls. Incubation was followed by three PBS washings. Flow cytometry measurement was performed using appropriate fluorescence compensation and light scatter gating, excluding dead cells, in a FACS SCAN Cytometer (Becton Dickinson). At least 400,000 events were measured within the lymphocyte gate. Analysis was performed using the fluorescence-1/fluorescence-2 dot plot quadrant statistics and manual gating (Cell Quest Pro Software, Becton Dickinson). In our laboratory, the intra-assay coefficient of variation was $6 \%$ for total $\mathrm{CD}_{3} 4^{+}$and $\mathrm{CD} 133^{+}$evaluation, $15.5 \%$ for $\mathrm{CD} 34^{+}$/ $\mathrm{KDR}^{+}$, and $16.8 \%$ for $\mathrm{CD} 133^{+} / \mathrm{VE}-\mathrm{Cadherin}^{+}$cells.

The calculation of total cell numbers of $\mathrm{CD}_{3} 4^{+}$or $\mathrm{CD} 133^{+}$and their subpopulations was obtained by multiplying the percentage of these cells (measured by FACS analysis on a lymphocyte gate) for total lymphocyte cell count.

Natural killer cell evaluation. To determine the number of natural killer (NK) cells, PBMC were labeled with a PE-conjugated antihuman CD56 mAb (Becton Dickinson), the lymphocyte cell population was gated, and the percentage of $\mathrm{CD}^{2} 6^{+}$cells (dim and bright) cells was determined. The number of $\mathrm{NK}\left(\mathrm{CD} 56^{+}\right)$lymphocytes per milliliter of blood was obtained by multiplying the percentage of

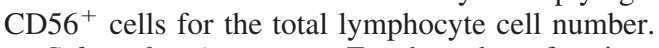

Colony forming assays. For the colony forming unit (CFU) assay, PBMCs were seeded at $3 \times 10^{5}$ cells $\cdot \mathrm{ml}^{-1} \cdot \mathrm{dish}^{-1}$ (Falcon 1008; Becton Dickinson) in $0.9 \%$ methylcellulose and $40 \%$ fetal calf serum (GIBCO, Grand Island, NY) in Iscove's modified Dulbecco's medium (GIBCO), which was supplemented with $1.5 \mathrm{IU} / \mathrm{ml}$ erythropoietin for erythrocyte burst-forming units (E-BFU) colonies, $10 \mathrm{ng} / \mathrm{ml}$ of both granulocyte-monocyte colony stimulating factor (GM-CSF), and G-CSF for granulocyte-monocyte colony-forming units (GM-CFU). For CFU-GEMM colonies assay (Colony Forming Units-Granulocyte, Erythrocyte, Monocyte, Megakaryocyte), all the growth factors used for BFU-E and CFU-GM colony assays were added together.

Colonies were counted under an inverted microscope after 14-16 days of culture. Data are expressed as the number of colonies per milliliter of blood.

Monocyte-derived angiogenic cells (CACs): isolation and characterization. Monocyte-derived angiogenic cells were obtained by in vitro growth of PBMCs using a procedure previously reported by Kalka et al. (13). After resuspension in endothelial basal medium (EBM-2; Clonetics) supplemented with EGM-2-MV-SingleQuots (Clonetics) containing VEGF, basic fibroblast growth factor, insulinlike growth factor-1, epidermal growth factor, and $10 \% \mathrm{FBS}, 1 \times 10^{6}$ cells $/ \mathrm{cm}^{2}$ were plated on fibronectin-coated tissue culture dishes. After 4 days of culture, nonadherent cells were discarded by washing with PBS, and adherent cells were cultured in the same endothelial culture medium usually for 7-10 days and up to $3 \mathrm{wk}$. To confirm the EPC phenotype, adherent cells were incubated with Dil-labeled acLDL (Molecular Probes) for $1 \mathrm{~h}$, and after fixation were incubated with FITC-labeled Ulex europaeus agglutinin 1 for $1 \mathrm{~h}$. Cells were visualized with an inverted microscope equipped for fluorescence, and adherent cells staining positive for both markers were judged to be 
monocytic angiogenetic cells. These cells were characterized also for the expression of membrane endothelial markers [i.e., VE-Cadherin (CD144), KDR (VEGF-R2), Tie-2, CD31, CD151, CD34]. The monocytic origin of these cells was confirmed by the positivity for CD14 antigen expression.

Evaluation of growth factor and cytokine concentrations. Aliquots of plasma and serum were prepared and stored at $-80^{\circ} \mathrm{C}$ for determination by immunoassay (ELISA, R\&D Systems, Minneapolis, MN) of the following pro-angiogenetic factors, as previously described (11): 1) VEGF-A, as a marker of tissue hypoxia and angiogenesis (detection limit: $0.5 \mathrm{pg} / \mathrm{ml}$ ); 2) VEGF-C and VEGF-D, known to induce mitogenesis, migration and survival of endothelial cells, and lymphoangiogenesis (detection limit: $5 \mathrm{pg} / \mathrm{ml}$ ); 3) HGF, a mediator known to activate proliferation and migration of endothelial cells and induce angiogenesis (detection limit: $20 \mathrm{pg} / \mathrm{ml}$ ); 4) SCF acting on early hemopoiesis (detection limit: $5.0 \mathrm{pg} / \mathrm{ml}$ ); 5) Ang-1 known to strongly promote angiogenesis through the Tie-2 receptor pathway (detection limit: $10 \mathrm{pg} / \mathrm{ml}$ ); and 6) Ang-2 known to be involved in the induction of inflammation (detection limit: $10 \mathrm{pg} / \mathrm{ml}$ ). IL-6 was assessed by immunoassay (ELISA, detection limit: $0.16 \mathrm{pg} / \mathrm{ml}, \mathrm{R} \& \mathrm{D}$ Systems).

Muscle enzymes (lactic dehydrogenase or LDH and creatine kinase or CK) were measured by enzymatic assays (Olympus 640 kits and equipment, Olympus Diagnostica, Hamburg, Germany) only in the marathon protocol, since they were previously found to be unchanged after short-lived exercise (22).

Statistics. Data are reported as means \pm SD or median (interquartile range). Analysis was performed by a statistical software (Statview 5.01, SAS Institute, Cary, NC). ANOVA with Bonferroni correction (or Kruskal-Wallis test for non-normally distributed variables) were used to compare results at different time points in the marathon protocol. Paired $t$-test was used to assess exercise-induced changes from baseline in the field test protocol. Unpaired $t$-test was used to compare baseline values from both protocols and exercise-induced changes in angiogenetic progenitors and growth factors between protocols. Linear regression was used to assess correlations between variables. Significance was at $P<0.05$ for all tests.

\section{RESULTS}

Blood cell counts. Table 1 reports the main data on blood cell counts in both protocols (marathon and 1,500-m field test). A marked rise in white blood cell counts associated with a moderate rise in platelet counts was observed at the end of the marathon race, returning toward baseline values the morning post-race (Table 1). White blood cell counts also increased after the field test but to a lesser extent compared with the marathon race. Intense neutrophilia was observed only after the marathon race. After the field test, lymphocyte counts and the natural killer subpopulation $\left(\mathrm{CD}^{+} 6^{+}\right)$increased significantly.
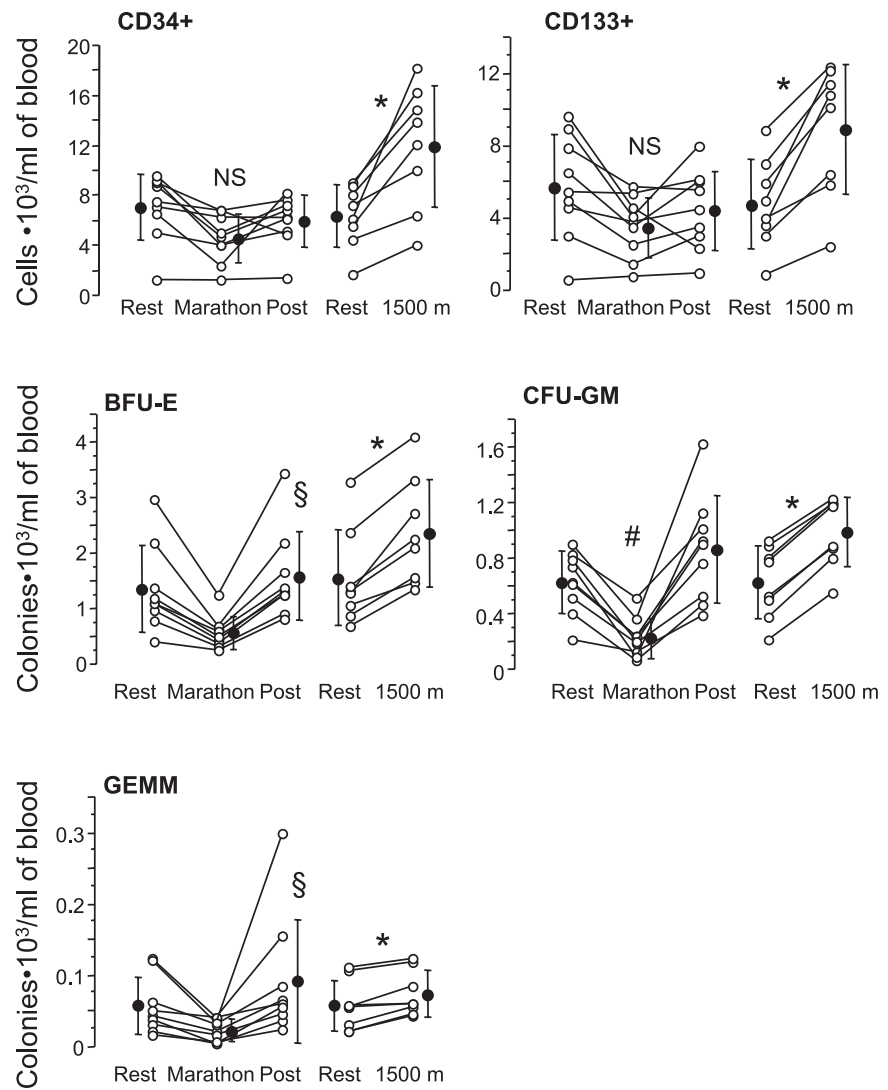

Fig. 1. Effects of a marathon race and of $1.5-\mathrm{km}$ field test on circulating hemopoietic progenitors. Top left: $\mathrm{CD} 34^{+}$cells. Top right: $\mathrm{CD} 133^{+}$cells Middle left: burst forming unit for erythrocytes (BFU-E). Middle right: granulocyte-monocyte colony forming units (CFU-GM). Bottom: granulocyte, erythrocyte, monocyte, and megacariocyte colony forming units (GEMM$\mathrm{CFU})$. See text for methodological details. Significant difference $(P<0.05)$ : *vs. rest; §vs. race; \#vs. rest and post-race.

Changes of $\mathrm{CD}_{3} 4^{+}$and $\mathrm{CD} 133^{+}$cells. The number of total CD $34^{+}$cells, as evaluated by flow cytometry, was virtually unaffected by the marathon race (pre-race: 6,800 \pm 932; end of race: $4,550 \pm 727$ cells $/ \mathrm{ml}$ of blood; post-race: $5,810 \pm 741$ cells/ml of blood; $P=$ not significant by ANOVA) (Fig. 1). Conversely, analysis of hemopoietic progenitor cells using a standard clonogenetic assay showed a significant decline in the number of colonies at the end of the race returning to baseline values the following morning (Fig. 1; BFU-E: $P<0.01$, post-race vs. end of race; CFU-GM: $P<0.005$ pre- and

Table 1. Blood cell counts

\begin{tabular}{|c|c|c|c|c|c|}
\hline & \multicolumn{3}{|c|}{ Marathon } & \multicolumn{2}{|c|}{ Field Test } \\
\hline $\mathrm{RBC}, \cdot 10^{6} / \mu \mathrm{l}$ & $4.71 \pm 0.30$ & $4.80 \pm 0.29$ & $4.56 \pm 0.35$ & $4.72 \pm 0.34$ & $5.00 \pm 0.30$ \\
\hline Platelets, $\cdot 10^{3} / \mu 1$ & $204 \pm 27$ & $311 \pm 62 \dagger$ & $214 \pm 45$ & $241 \pm 50$ & $272 \pm 44$ \\
\hline $\mathrm{WBC}, \cdot 10^{3} / \mu \mathrm{l}$ & $6.74 \pm 2.17$ & $17.33 \pm 3.71 \dagger$ & $7.48 \pm 1.62$ & $6.76 \pm 1.89$ & $10.91 \pm 3.18 *$ \\
\hline Neutrophils, $\cdot 10^{3} / \mu 1$ & $3.63 \pm 1.11$ & $14.45 \pm 3.12 \dagger$ & $4.71 \pm 2.01$ & $3.71 \pm 1.04$ & $5.61 \pm 2.53$ \\
\hline Lymphocytes, $\cdot 10^{3} / \mu 1$ & $2.24 \pm 0.90$ & $1.86 \pm 0.65$ & $2.01 \pm 0.73$ & $2.28 \pm 0.81$ & $4.15 \pm 0.92^{*}$ \\
\hline
\end{tabular}

Values are means \pm SE. RBC, red blood cell; Hct, hematocrit; WBC, white blood cell; NK, natural killer. Significant difference $(P<0.05): * v s$. baseline; $\dagger v s$. baseline and post-race. 
post-race vs. end of race; CFU-GEMM: $P<0.05$, post-race vs. end of race).

After the field test, both the number of circulating $\mathrm{CD} 34^{+}$cells and the number of progenitors assessed by colony assays increased significantly (Fig. 1; CD $34^{+}$cells: $P<0.005$; BFU-E: $P<0.0001$; CFU-GM: $P<0.0001$; CFU-GEMM: $P<0.005$ ).

$\mathrm{CD} 133^{+}$cells showed a pattern of release similar to that observed for $\mathrm{CD}_{3} 4^{+}$cells (Fig. 1), i.e, no changes during or after the marathon race $(P=$ not significant $)$ and increase after the field test $(P<0.001)$.

Endothelial progenitors. Two subpopulations of endothelial progenitors were evaluated by flow cytometry: 1 ) endothelial progenitor cells (EPCs) that co-express stem cell/progenitor cell markers, such as CD34 or CD133, and endothelial markers, such as KDR or VE-Cadherin; 2) monocyte-derived endothelial cells, known as circulating angiogenic cells (CAC).

For the evaluation of EPCs, aliquots of $1 \times 10^{6}$ PBMCs were incubated with anti-KDR-PE and anti-CD34-FITC or anti-VE-Cadherin-PE and anti-CD34-FITC. The number of $\mathrm{CD}^{+} 4^{+}$/ $\mathrm{KDR}^{+}$or $\mathrm{CD} 34^{+} / \mathrm{VE}-\mathrm{Cadherin}{ }^{+}$cells was analyzed in the small lymphocyte region (see a representative analysis in Fig. 2). The number of $\mathrm{CD}_{133}{ }^{+} \mathrm{VE}-\mathrm{Cadherin}{ }^{+}$or $\mathrm{CD} 34^{+} \mathrm{KDR}^{+}$cells assessed by flow cytometric analysis showed a nearly twofold increase in peripheral blood at the end of the marathon race $\left(\mathrm{CD} 133^{+}\right.$VE-Cadherin ${ }^{+}$cells: $P<0.05$, end of race vs. pre-race; $\mathrm{CD} 34^{+} \mathrm{KDR}^{+}$cells: $P<0.005$, end of race vs. pre- and post-race) and returning to baseline values the following morning (Fig. 3, $A$ and $B)$. The exercise-induced increase in the number of $\mathrm{CD} 133^{+}$Ve-Cadherin ${ }^{+}$and $\mathrm{CD} 34^{+} \mathrm{KDR}^{+}$cells was more pronounced (nearly threefold) after the field test (Fig. 3, $A$ and $B$;
CD $133^{+}$VE-Cadherin ${ }^{+}$cells: $P<0.01 ; \mathrm{CD}^{2} 4^{+} \mathrm{KDR}^{+}$cells: $P<0.01)$. In contrast, cells positive for CD133 but negative for VE-Cadherin $\left(\mathrm{AC}_{133^{+}} \mathrm{VE}^{-\mathrm{Cadherin}^{-}}{ }^{-}\right.$, mainly representing hemopoietic progenitors and immature hemopoietic precursors, showed a moderate decrease at the end of race (data not shown).

Analysis of CACs showed a marked increase from baseline values $\left(8,489 \pm 1,850\right.$ cells $\left./ 1 \times 10^{6} \mathrm{PBMCs}\right)$ to post-marathon values $\left(30,210 \pm 4,560 / 1 \times 10^{6} \mathrm{PBMCs}\right)$, returning almost to baseline $\left(10,861 \pm 1,818\right.$ cells $/ 1 \times 10^{6}$ PBMCs $)$ the morning post-race (ANOVA: $P<0.0001$, end of race vs. pre- and post-race; Fig. $3 C$ ). CACs also increased after the field test, although to a lesser extent $(P<0.005)$. Figure $3 D$ summarizes the effects of the two exercise protocols on angiogenetic progenitor subpopulations. $\mathrm{KDR}^{+}$cells increased similarly in the two protocols. Conversely, CD133 ${ }^{+}$VE-cadherin ${ }^{+}$cells increased especially after the field test $(P<0.01)$, whereas CAC increased preferentially after the marathon race $(P<$ $0.01)$.

Growth factors and mediators. Table 2 summarizes the results of the measurements in serum/plasma in the marathon and field test protocols. Similar to our previous study (3), IL-6 increased after both exercise protocols (marathon: ANOVA $P<0.0001$; field test: $P<0.05$ ), but the increase after the marathon race was much larger than after the field test. HGF (marathon: ANOVA $P<0.0001$; field test: $P<0.01$ ) and SCF levels (marathon: ANOVA $P<0.01$; field test: $P<0.05$ ) increased similarly after both protocols. VEGF-A and VEGF-D levels were not significantly affected by either type of exercise, and the former showed a tendency to decrease after the marathon.
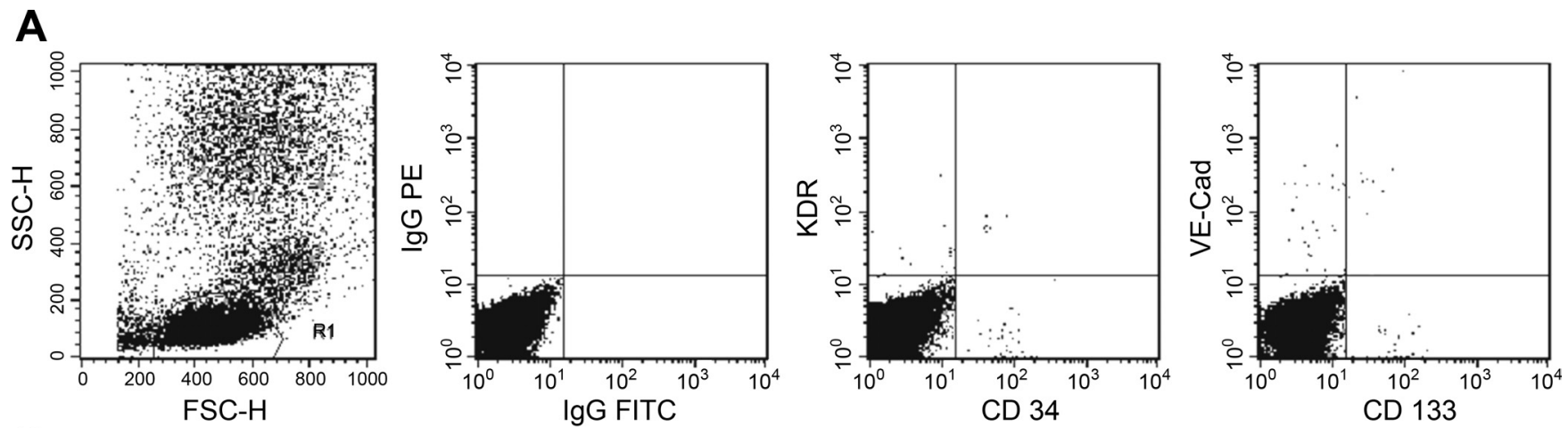

B
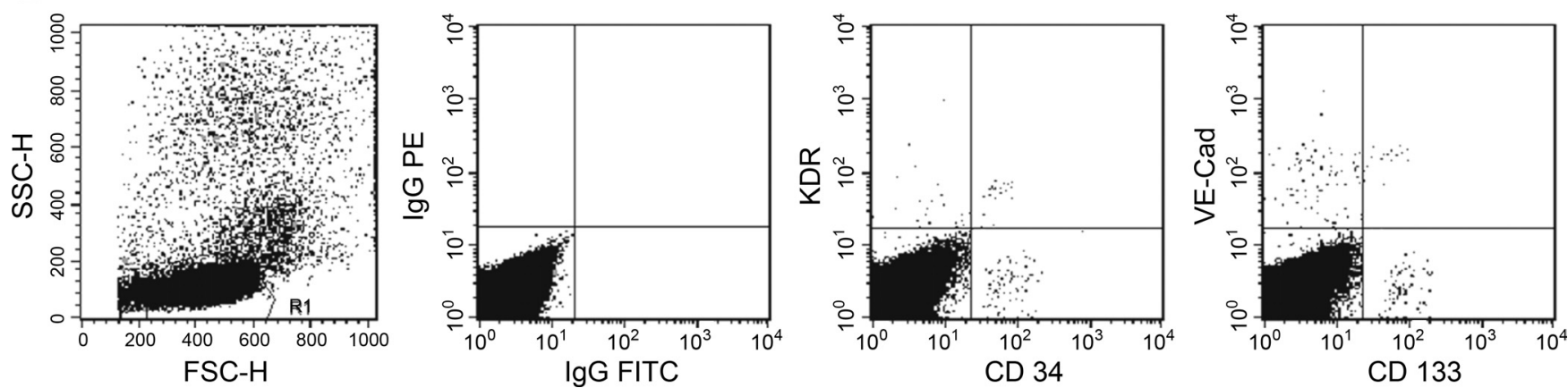

Fig. 2. Flow cytometry analysis of endothelial progenitor cells (EPCs) in peripheral blood (PB) in one subject at baseline (top) and after the 1.5-km field test (bottom). Mononuclear cells isolated from PB were gated in a forward-scatter (FSC)/side-scatter (SSC) plot (left): the cell population corresponding to small lymphocytes was gated and analyzed for background fluorescence after labeling with isotype-matched control mouse IgGs (second panel from left), for CD34 ${ }^{+}$ and $\mathrm{KDR}^{+}$cells after labeling with anti-CD34 and anti-KDR mAbs (third panels from left), or for CD133 ${ }^{+}$and VE-Cadherin ${ }^{+}$cells after labeling with anti-CD133 and anti-VE-Cadherin mAbs (right). 
Fig. 3. Effects of a marathon race and of $1.5-\mathrm{km}$ field test on circulating angiogenetic progenitors. $A$ and $B$ : the results of flow cytometric analysis

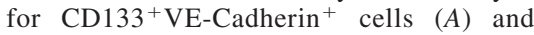
$\mathrm{CD} 4^{+} \mathrm{KDR}^{+}(B)$ cells, respectively. $C$ : the results of the clonogenetic assay for angiogenetic cells. $D$ : exercise-induced changes in endothelial progenitors after the marathon race (shaded bars) and after the $1.5-\mathrm{km}$ field test (open bars), expressed as \% change from baseline. See text for methodological details. Significant difference $(P<0.05)$ : *vs. rest; §vs. pre-race; \#vs. rest and post-race. $* *$ Significant difference in the response to marathon and field test.

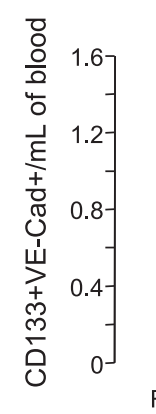

A
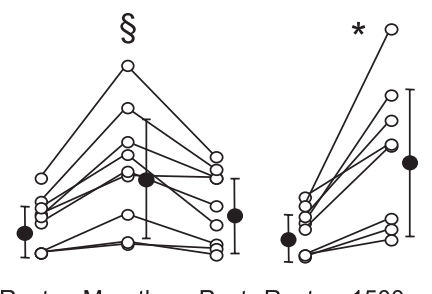

Rest Marathon Post Rest $1500 \mathrm{~m}$
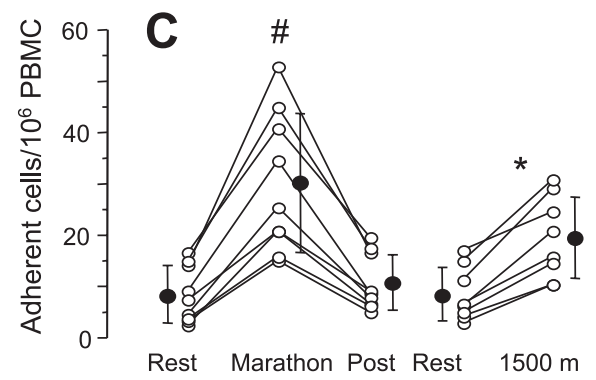
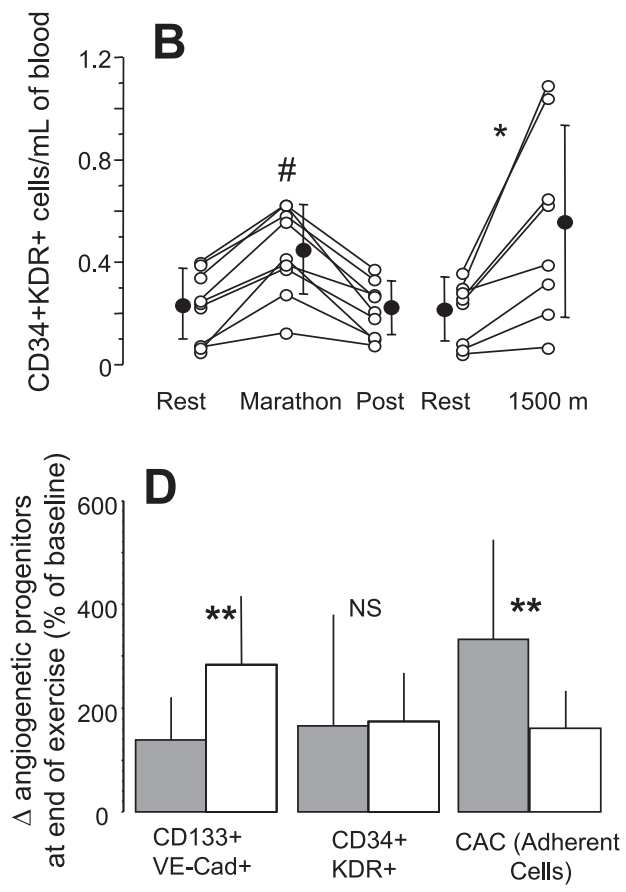

VEGF-C increased the day after the marathon race, whereas its change immediately post-race did not reach statistical significance (marathon: ANOVA $P<0.05$ ); a small but significant increase in VEGF-C level was observed at the end of the field test $(P<0.001)$. Ang-1 increased significantly after exercise only in the marathon protocol, with a similar trend after the field test (marathon: ANOVA $P<0.01$; field test: $P=0.06$; Fig. 4). Ang-2 increased significantly after exercise in both tests (marathon: ANOVA $P<0.001$; field test: $P=0.005$, Fig. 4 ), whereas the ratio of Ang-1 to Ang-2 was unaffected by either type of exercise (Fig. 4 and Table 2).

Figure 5 summarizes the change in cytokine/growth factor concentrations from baseline to immediate postexercise conditions in both protocols. Changes from baseline to postexercise were larger after the marathon race than after the field test for HGF $(P=0.01)$ and VEGF-D $(P=0.01)$, suggesting a dose- response relationship between endurance and maximal exercise and release of these growth factors.

\section{DISCUSSION}

This study shows that, in trained amateur runners, release of bone marrow-derived progenitors differed between a marathon race and a maximal field test over $1,500 \mathrm{~m}$. The data extend our previous findings in amateur runners (3) by showing that postexercise $\mathrm{CD} 34^{+}$cell counts likely result from a complex response to prolonged endurance exercise (i.e., marathon), characterized by decreased circulating hemopoietic progenitors and increased mobilization of angiogenetic progenitors. The response to the maximal field test was similar to the one found in rowers after supramaximal exercise (22), since both hemopoietic and angiogenetic progenitors increased immediately

Table 2. Growth factors and mediators

\begin{tabular}{|c|c|c|c|c|c|}
\hline & \multicolumn{3}{|c|}{ Marathon } & \multicolumn{2}{|c|}{ Field Test } \\
\hline IL-6, pg/ml & $0.79 \pm 0.51$ & $14.74 \pm 2.35^{\mathrm{a}}$ & $0.98 \pm 0.44$ & $0.67 \pm 0.46$ & $1.50 \pm 1.10^{\mathrm{e}}$ \\
\hline VEGF-A, pg/ml & $185 \pm 111$ & $137 \pm 133$ & $201 \pm 163$ & $208 \pm 114$ & $194 \pm 113$ \\
\hline VEGF-C, $\mathrm{ng} / \mathrm{ml}$ & $6.4 \pm 1.9$ & $9.4 \pm 3.5$ & $11.2 \pm 5.0^{\mathrm{c}}$ & $7.3 \pm 1.8$ & $8.8 \pm 1.7^{\mathrm{e}}$ \\
\hline VEGF-D, $\mathrm{ng} / \mathrm{ml}$ & $0.7 \pm 0.5$ & $1.0 \pm 0.8$ & $0.3 \pm 0.4$ & $0.4 \pm 0.2$ & $0.5 \pm 0.2$ \\
\hline Ang-1, ng/ml & $6.4 \pm 9.9$ & $13.4 \pm 6.3^{\mathrm{c}}$ & $9.0 \pm 5.6$ & $6.4 \pm 1.9$ & $7.1 \pm 1.6$ \\
\hline $\mathrm{SCF}, \mathrm{pg} / \mathrm{ml}$ & $754 \pm 120$ & $943 \pm 141^{c}$ & $813 \pm 105$ & $905 \pm 124$ & $1023 \pm 157^{e}$ \\
\hline $\mathrm{CK}, \mathrm{IU}$ & $159 \pm 56$ & $233 \pm 94$ & $793 \pm 512^{\mathrm{d}}$ & nd & nd \\
\hline LDH, IU & $464 \pm 92$ & $683 \pm 143^{b}$ & $527 \pm 117$ & nd & nd \\
\hline
\end{tabular}

Values are means \pm SE. HGF, hepatocyte growth factor; Ang, angiopoietin; SCF, stem cell factor; CK, creatine kinase; LDH, lactic dehydrogenase; nd, not determined. ${ }^{\text {aEnd }}$ of marathon significantly different from pre-race and post-race $\left(P<0.05\right.$, ANOVA). ${ }^{\text {b} E n d ~ o f ~ m a r a t h o n ~ s i g n i f i c a n t l y ~ d i f f e r e n t ~ f r o m ~ p r e-r a c e ~}$ and post-race $\left(P<0.05\right.$, Kruskal-Wallis test). ${ }^{\mathrm{c}}$ Significantly different from pre-race $\left(P<0.05\right.$, ANOVA). ${ }^{\mathrm{d}}$ Significantly different from pre-race and end of

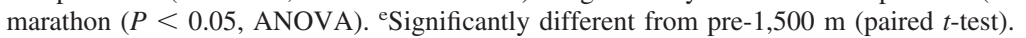



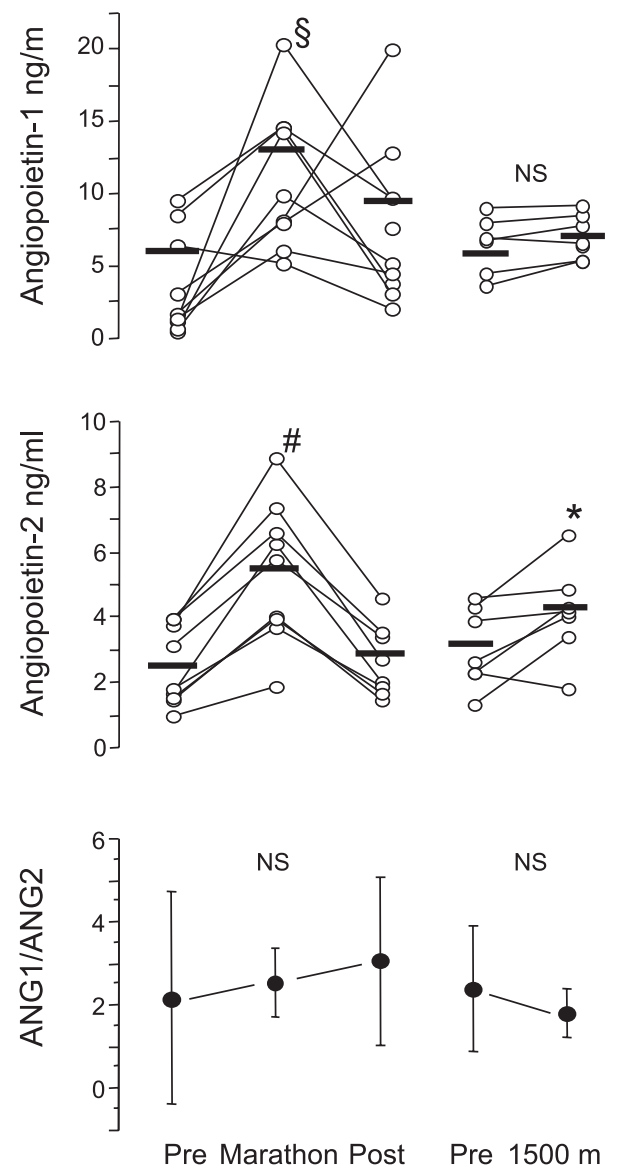

Fig. 4. Effects of a marathon race and of a $1.5-\mathrm{km}$ field test on plasma angiopoietin-1 (top) and angiopoietin-2 (middle) levels. The ratio between angiopoietin-1 and -2 was unaffected by exercise (bottom). See text for methodological details. Significant difference $(P<0.05)$ : *vs. rest; §vs. pre-race; \#vs. rest and post-race.

after exercise. These changes were associated with a different pattern of release of growth/angiogenetic factors, suggesting that the time course of progenitor release is modulated by the type of exercise.

As an explanation for our findings, we hypothesize that, during the marathon race, hemopoietic progenitors may migrate from blood to peripheral tissues, whereas in the hours following the end of the race a normal number of peripheral blood hemopoietic progenitors is rapidly restored through the migration of progenitors from bone marrow to peripheral blood. Conversely, acute intense exercise mobilized progenitors from the bone marrow. Our study extends the data recently reported by Adams and coworkers (2) by showing that the decrease in circulating hemopoietic progenitors after a marathon race is not a peculiar response of aged individuals but also occurs in younger athletes (average age in our sample was 43 yr vs. 57 yr in Adams' study). Another study on long-distance runners examined athletes after a $246-\mathrm{km}$ race (10) and documented a long-lasting release of EPCs after the race. In our study, all changes in progenitors were short-lived and had returned to baseline the day after the race. The extreme features of Spartathlon compared with marathon probably account for the difference in results between studies.

In addition to total $\mathrm{CD} 34^{+}$progenitors, we measured the changes in the number of different hemopoietic progenitor types (BFU-E, CFU-GM, and CFU-GEMM) occurring after a marathon race or a maximal field test, providing evidence that the changes in the number of these hemopoietic populations strictly reflected the changes observed in total $\mathrm{CD} 34^{+}$cells. Interestingly, similar changes in BFU-E numbers have been observed in athletes participating in the ultra-marathon Spartathlon (35).

A most interesting finding regards the behavior of different subpopulations of angiogenetic progenitors. $\mathrm{CD} 34^{+} \mathrm{KDR}^{+}$cells, $\mathrm{CD} 133^{+}$VE-cadherin ${ }^{+}$cells, and monocyte-derived CACs appeared to be highly regulated in athletes, and their response modulated by the type of exercise. Indeed, $\mathrm{CD} 34^{+} \mathrm{KDR}^{+}$cells increased similarly after the marathon and the field test. Con-

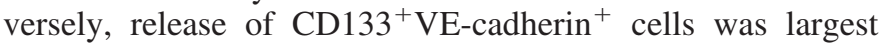
after the field test, whereas release of CAC preferentially occurred after the marathon. These findings suggest a highly regulated and possibly redundant system preserving endothelial function and capillarization in response to intense exercise in normal subjects. Differently from our results, Adams and coworkers (2) reported unchanged number of $\mathrm{CD} 34^{+} \mathrm{KDR}^{+}$ cells after the marathon race, but the proportion of angiogenetic progenitors out of total progenitor counts increased postrace also in their study. The older age of their sample may at least partly account for different results. The same group recently reported an increase in both total $\mathrm{CD} 34^{+}$cells and $\mathrm{CD} 34^{+} / \mathrm{KDR}^{+} \mathrm{EPCs}$ at the end of strenuous endurance exercise ( $4 \mathrm{~h}$ of cycling) (21), a condition similar to that observed by us after the marathon race. Overall, these studies suggest that endurance exercise induces a preferential differentiation of $\mathrm{CD} 34^{+}$cells toward EPCs. Alternatively, it can be hypothesized that EPCs are directly mobilized from the bone marrow by defined stimuli triggered by exercise. As for the physiological relevance of exercise-induced EPC mobilization on skeletal muscle, most studies have used models of limb ischemia, i.e., a likely different stimulus compared with exercise in normal subjects. The available data do suggest that exerciseinduced mobilization of EPC is associated with transcription of VEGF-A in muscle tissue (38) and likely promotes new vessel formation. However, an additional role of EPC on proliferation of skeletal muscle cells cannot be excluded as suggested by some experimental data obtained in a limb ischemia model (19).

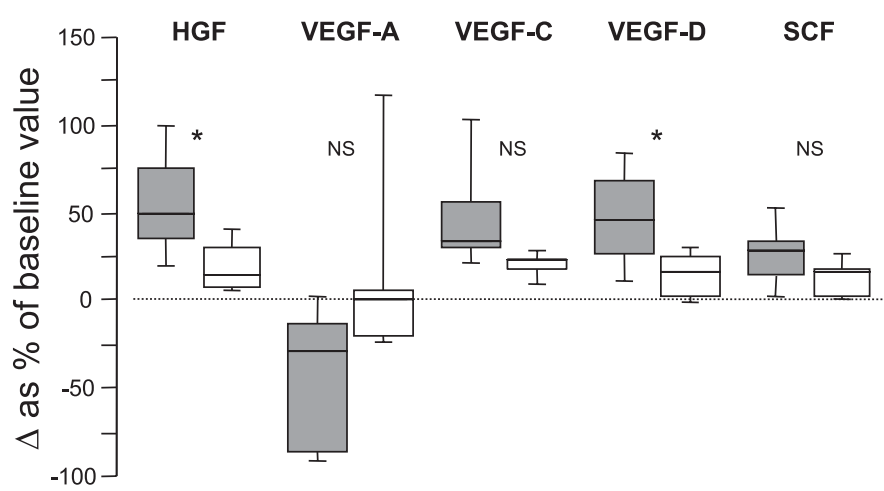

Fig. 5. Exercise-induced changes in growth factors after the marathon race (shaded) and after the $1.5-\mathrm{km}$ field test (open), expressed as $\%$ change from baseline. HGF, hepatocyte growth factor; VEGF, vascular endothelial growth factor; SCF, stem cell factor. *Significant difference between changes observed after the marathon and field test $(P<0.05)$. 
Our study may also be interpreted as providing information on the time course of progenitor release, with changes after the field test mainly representing the early response to exercise, whereas the changes after the marathon would indicate the response to prolonged aerobic exercise.

Our protocol is hardly comparable to that used by Laufs and coworkers (17), but the postexercise increase in $\mathrm{CD} 34^{+} \mathrm{KDR}^{+}$ cells we observed is of the same order of magnitude as the one reported by these authors after $30 \mathrm{~min}$ of running in young healthy subjects.

Exercise-induced release of progenitors was associated with release of growth factors, which may help to understand the mechanisms involved in progenitor mobilization. A dose-response effect, with higher plasma concentrations after the marathon compared with the field test, was evident for IL-6, HGF, and angiopoietins, whereas SCF increased similarly in both protocols. Increased IL-6 after exercise has been repeatedly reported, also by our group, and suggests activation of inflammatory mechanisms during intense exercise in a dosedependent fashion $(3,10)$. The increased SCF value suggests, together with our previous report of release of Flt3-ligand after exercise (3), a possible trophic effect of exercise on the bone marrow. Interestingly, bone marrow adipocytes decreased and osteoblasts increased in response to exercise training in mice (20). Since bone marrow adipocytes have been shown to exert negative effects on hematopoiesis (23), we speculate that a decreased number of adipocytes in the bone marrow may be one mechanism by which exercise exerts a trophic effect on bone formation and hematopoiesis.

Plasma VEGF-A was unaffected by either exercise protocol. Our data therefore agree with other reports of unchanged plasma VEGF-A concentration after exercise in normal subjects $(2,18,28,39)$, suggesting that peripheral blood does not reflect the exercise-induced VEGF-A expression that occurs in skeletal muscle (8). Instead, increased plasma VEGF-A concentration after exercise has been found in patients with ischemic vascular disease $(1,30,34)$, heart failure $(6)$, or chronic obstructive pulmonary disease (24), confirming a pivotal role of hypoxia in causing VEGF-A release in peripheral blood. A shift toward anaerobic metabolism during exercise may also account for the slight increase in VEGF-A previously found in our study in rowers after all-out exercise (22).

Little is known about the effects of exercise on plasma concentrations of VEGF-C and VEGF-D. Both growth factors, initially described as mediators of lymphatic vessel development, are believed to be involved in new capillary growth under normal and pathological conditions (36). Exercise has been rarely investigated as a modulator of lymphatic vessel development, but a study in mice found minor effects of acute exercise and no change in lymphatics after training (14). In our study VEGF-D increased more after the marathon than after the field test, but the changes observed after exercise were small compared with the other growth factors investigated, in line with previous experimental data.

Among the growth factors of potential interest, the HGF is a potent angiogenetic mediator. We previously reported increased HGF concentrations after supramaximal exercise in rowers (22) and after endurance exercise in patients with chronic obstructive pulmonary disease (24). The present study extends previous data by showing a significant increase in HGF in healthy athletes, irrespective of the type of exercise. More- over, recent data suggest that HGF may also modulate lymphangiogenesis (5).

Angiopoietins are important physiological factors acting in concert with other angiogenetic factors to regulate blood vessel stability and permeability (7). The plasma level of Ang-1 and Ang-2 measured in well trained runners at rest were in the same range as measured in aged healthy controls (6). Both Ang-1 and Ang-2 increased after exercise, but their ratio remained stable after exercise in both protocols. Elevated plasma Ang-2 concentration has been found in critically ill patients (15) and in advanced chronic obstructive pulmonary disease patients (11), in agreement with its involvement in inflammation. The stability of the Ang-1-to-Ang-2 ratio suggests that intense exercise is not a significant pro-inflammatory stimulus for endothelial cells in trained normal subjects.

Our study shows some limitations. First, due to the field type of studies, only a small number of subjects could be included, preventing correlation analysis between progenitor cell counts and growth factor concentrations. Second, measurements of progenitor cells in peripheral blood can only provide indirect information on the bone marrow. Ethical reasons do not allow bone marrow samples to be obtained from healthy subjects. Finally, our results were obtained in a selected population of well trained amateur athletes.

In conclusion, our study in healthy runners shows a complex modulation of progenitor and mediator release after exercise, with different patterns observed after endurance or maximal exercise. Maximal exercise is associated with release of both hemopoietic and endothelial progenitors, whereas high numbers of circulating endothelial progenitors are found after prolonged endurance exercise together with reduced hemopoietic progenitor counts. These findings suggest peripheral utilization of bone marrow-derived cells during strenuous endurance exercise. The different pattern of release of endothelial progenitors during prolonged and short-lived maximal exercise suggests very efficient and redundant angiogenetic mechanisms operating in healthy endurance-trained subjects.

\section{REFERENCES}

1. Adams V, Lenk K, Linke A, Lenz D, Erbs S, Sandri M, Tarnok A, Gielen S, Emmrich F, Schuler G, Hambrecht R. Increase of circulating endothelial progenitor cells in patients with coronary artery disease after exercise-induced ischemia. Arterioscler Thromb Vasc Biol 24: 684-690, 2004.

2. Adams V, Linke A, Breuckmann F, Leineweber K, Erbs S, Kränkel N, Bröcker-Preuss M, Woitek F, Erbel R, Heusch G, Hambrecht R, Schuler G, Möhlenkamp S. Circulating progenitor cells decrease immediately after marathon race in advanced-age marathon runners. Eur $J$ Cardiovasc Prev Rehabil 15: 602-607, 2008.

3. Bonsignore MR, Morici G, Santoro A, Pagano M, Cascio L, Bonanno A, Insalaco G, Abate P, Mirabella F, Profita M, Gioia M, Vignola AM, Majolino I, Testa U, Hogg JC. Circulating hematopoietic precursor cells (HPCs) in well-trained runners. J Appl Physiol 93: 1691-1697, 2002.

4. Bussolino F, Di Renzo MF, Ziche M, Bocchietto E, Olivero M, Naldini L, Gaudino G, Tamagnone L, Coffer A, Comoglio PM. Hepatocyte growth factor is a potent angiogenic factor which stimulates endothelial cell motility and growth. J Cell Biol 119: 629-641, 1992.

5. Cao R, Björndahl MA, Gallego MI, Chen S, Religa P, Hansen AJ, Cao Y. Hepatocyte growth factor is a lymphangiogenic factor with an indirect mechanism of action. Blood 107: 3531-3536, 2006.

6. Chong AY, Caine GJ, Freestone B, Blann AD, Lip GYH. Plasma angiopoietin-1, angiopoietin-2, and angiopoietin receptor Tie-2 levels in congestive heart failure. J Am Coll Cardiol 43: 423-428, 2004.

7. Fiedler U, Augustin HG. Angiopoietins: a link between angiogenesis and inflammation. Trends Immunol 27: 552-558, 2006. 
8. Gavin TP, Drew JL, Kubik CJ, Pofahl WE, Hickner RC. Acute resistance exercise increases skeletal muscle angiogenic growth factor expression. Acta Physiol 191: 139-146, 2007.

9. Gonzales C, Pedrazzini T. Progenitor cell therapy for heart disease. Exp Cell Res 315: 3077-3085, 2009.

10. Goussetis E, Spiropoulos A, Tsironi M, Skenderi K, Margeli A, Graphakos S, Baltopoulos P, Papassotiriou I. Spartathlon, a 246 kilometer foot race: effects of acute inflammation induced by prolonged exercise on circulating progenitor reparative cells. Blood Cells Mol Dis 42: 294-299, 2009.

11. Huertas A, Testa U, Riccioni R, Petrucci E, Riti V, Savi D, Serra P, Bonsignore MR, Palange $\mathbf{P}$. Bone marrow-derived progenitors are greatly reduced in patients with severe COPD and low BMI. Respir Physiol Neurobiol 170: 23-31, 2010.

12. Jussila L, Alitalo K. Vascular growth factors and lymphangiogenesis. Physiol Rev 82: 673-700, 2002.

13. Kalka C, Masuda H, Takahashi T, Kalka-Moll W, Silver M, Kearney M, Li T, Isner JM, Asahara T. Transplantation of ex vivo expanded endothelial progenitor cells for therapeutic neovascularization. Proc Natl Acad Sci USA 97: 3422-3427, 2000.

14. Kivelä R, Silvennoinen M, Lehti M, Kainulainen H, Vihko V. Effects of acute exercise, exercise training, and diabetes on the expression of lymphangiogenic growth factors and lymphatic vessels in skeletal muscle. Am J Physiol Heart Circ Physiol 293: H2573-H2579, 2007.

15. Kümpers P, Lukasz A, David S, Horn R, Hafer C, Faulhaber-Walter R, Riser D, Haller H, Kielstein JT. Excess circulating angiopoietin-2 is a strong predictor of mortality in critically ill medical patients. Crit Care 12: R147, 2008.

16. LaBarge MA, Blau HM. Biological progression from adult bone marrow to mononucleate muscle stem cell to multinucleate muscle fiber in response to injury. Cell 111: 589-601, 2002.

17. Laufs U, Urhausen A, Werner N, Scharhag J, Heitz A, Kissner G, Böhm M, Kindermann W, Nickenig G. Running exercise of different duration and intensity: effect on endothelial progenitor cells in healthy subjects. Eur J Cardiovasc Prev Rehabil 12: 407-414, 2005.

18. Laufs U, Werner N, Link A, Endres M, Wassmann S, Jurgens K, Miche E, G, Böhm M, Nickenig G. Physical training increases endothelial progenitor cells, inhibits neointima formation, and enhances angiogenesis. Circulation 109: 220-226, 2004.

19. Madeddu P, Emanueli C, Pelosi E, Salis MB, Cerio AM, Bonanno G, Patti M, Stassi G, Condorelli G, Peschle C. Transplantation of low dose $\mathrm{CD} 34^{+} \mathrm{KDR}^{+}$cells promotes vascular and muscular regeneration in ischemic limbs. FASEB J 18: 1737-1739, 2004.

20. Menuki K, Mori T, Sakai A, Sakuma M, Okimoto N, Shimizu Y, Kunugita N, Nakamura T. Climbing exercise enhances osteoblast differentiation and inhibits adipogenic differentiation with high expression of PTH/PTHrP receptor in bone marrow cells. Bone 43: 613-620, 2008.

21. Mobius-Winkler S, Hilberg T, Menzel K, Golla E, Burman A, Schuler G, Adams V. Time-dependent mobilization of circulating progenitor cells during strenuous exercise in healthy individuals. J Appl Physiol 107: 1943-1950, 2009.

22. Morici G, Zangla D, Santoro A, Pelosi E, Petrucci E, Gioia M, Bonanno A, Profita M, Riccobono L, Bellia V, Testa U, Bonsignore MR. Supramaximal exercise mobilizes haematopoietic progenitors and reticulocytes in athletes. Am J Physiol Regul Integr Comp Physiol 289: R1496-R1503, 2005.

23. Naveiras O, Nardi V, Wenzel PL, Hauschka PV, Fahey F, Daley GQ. Bone-marrow adipocytes as negative regulators of the haematopoietic microenvironment. Nature 460: 259-263, 2009.

24. Palange P, Testa U, Huertas A, Pelosi E, Calabrò L, Antonucci R, Petrucci R, Pasquini L, Satta A, Morici G, Vignola AM, Bonsignore MR. Circulating haemopoietic and endothelial progenitor cells are decreased in COPD. Eur Respir J 27: 529-541, 2006.

25. Palermo AT, Labarge MA, Doyonnas R, Pomerantz J, Blau HM. Bone marrow contribution to skeletal muscle: a physiological response to stress. Dev Biol 279: 336-344, 2005.
26. Pompilio G, Capogrossi MC, Pesce M, Alamanni F, DiCampli C, Achilli F, Germani A, Biglioli P. Endothelial progenitor cells and cardiovascular homeostasis: clinical implications. Int J Cardiol 131: 156-167, 2009.

27. Rehman J, Li J, Orschell CM, March KL. Peripheral blood "endothelial progenitor cells" are dervied from monocyte/macrophages and secrete angiogenic growth factors. Circulation 107: 1164-1169, 2003.

28. Rehman J, Li J, Parvathaneni L, Karlsson G, Panchal VR, Temm CJ, Mahenthiran J, March KL. Exercise acutely increases circulating endothelial progenitor cells and monocyte-/macrophage-derived angiogenic cells. J Am Coll Cardiol 43: 2314-2318, 2004.

29. Rissanen TT, Markkanen JE, Gruchala M, Heikura T, Puranen A, Kettunen MI, Kholová I, Kauppinen RA, Achen MG, Stacker SA, Alitalo K, Ylä-Herttuala S. VEGF-D is the strongest angiogenic and lymphangiogenic effector among VEGFs delivered into skeletal muscle via adenoviruses. Circ Res 92: 1098-1106, 2003.

30. Sandri M, Adams V, Gielen S, Linke A, Lenk K, Kränkel N, Lenz D, Erbs S, Scheinert D, Mohr FW, Schuler G, Hambrecht R. Effects of exercise and ischemia on mobilization and functional activation of bloodderived progenitor cells in patients with ischemic syndromes: results of 3 randomized studies. Circulation 111: 3391-3399, 2005.

31. Schatteman GC, Dunnwald M, Jiao C. Biology of bone marrow-derived endothelial cell precursors. Am J Physiol Heart Circ Physiol 292: H1H18, 2007.

32. Shantsila E, Watson T, Lip GY. Endothelial progenitor cells in cardiovascular disorders. J Am Coll Cardiol 49: 741-752, 2007.

33. Shantsila E, Watson T, Tse HF, Lip GY. New insights on endothelial progenitor cell subpopulations and their angiogenic properties. J Am Coll Cardiol 51: 669-671, 2008.

34. Shintani S, Murohara T, Ikeda H, Ueno T, Honma T, Katoh A, Sasaki K, Shimada T, Oike Y, Imaizumi T. Mobilization of endothelial progenitor cells in patients with acute myocardial infarction. Circulation 103: 2776-2779, 2001.

35. Spiropoulos A, Goussetis E, Margeli A, Premetis E, Skenderi K, Graphakos S, Baltopoulos P, Tsironi M, Papassotiriou I. Effect of inflammation induced by prolonged exercise on circulating erythroid progenitors and markers of erythropoiesis. Clin Chem Lab Med 48: 199-203, 2010.

36. Tammela T, Enholm B, Alitalo K, Paavonen K. The biology of vascular endothelial growth factors. Cardiovasc Res 65: 550-563, 2005.

37. Tang Y, Yasuhara T, Hara K, Matsukawa N, Maki M, Yu G, Xu L, Hess DC, Borlongan CV. Transplantation of bone marrow-derived stem cells: a promising therapy for stroke. Cell Transplant 16: 159-169, 2007.

38. Tang K, Xia FC, Wagner PD, Breen EC. Exercise-induced VEGF transcriptional activation in brain, lung and skeletal muscle. Respir Physiol Neurobiol 170: 16-22, 2010.

39. Thijssen DH, Vos JB, Verseyden C, van Zonneveld AJ, Smits P, Sweep FC, Hopman MT, de Boer HC. Hematopoietic stem cells and endothelial progenitor cells in healthy men: effect of aging and training. Aging Cell 5: 495-503, 2006.

40. Van Craenenbroeck EM, Vrints CJ, Haine SE, Vermeulen K, Goovaerts I, Van Tendeloo VF, Hoymans VY, Conraads VM. A maximal exercise bout increases the number of circulating $\mathrm{CD} 34^{+} / \mathrm{KDR}^{+}$endothelial progenitor cells in healthy subjects. Relation with lipid profile. $J$ Appl Physiol 104: 1006-1013, 2008.

41. Wahl P, Bloch W, Schmidt A. Exercise has a positive effect on endothelial progenitor cells, which could be necessary for vascular adaptation processes. Int J Sports Med 28: 374-380, 2007.

42. Walther C, Adams V, Bothur I, Drechsler K, Fikenzer S, Sonnabend M, Bublitz B, Körner A, Erbs S, Busse M, Schuler G. Increasing physical education in high school students: effects on concentration of circulating endothelial progenitor cells. Eur J Cardiovasc Prev Rehabil 15: 416-422, 2008. 